University of Nebraska - Lincoln

DigitalCommons@University of Nebraska - Lincoln

1990

\title{
Intake and Digestion of Low-Quality Meadow Hay by Steers and Performance of Cows on Native Range When Fed Protein Supplements Containing Various Levels of Corn
}

\author{
D. W. Sanson \\ D. C. Clanton \\ University of Nebraska-Lincoln, don_clanton@comcast.net \\ Ivan G. Rush \\ University of Nebraska-Lincoln, irush1@unl.edu
}

Follow this and additional works at: https://digitalcommons.unl.edu/panhandleresext

Part of the Agriculture Commons

Sanson, D. W.; Clanton, D. C.; and Rush, Ivan G., "Intake and Digestion of Low-Quality Meadow Hay by Steers and Performance of Cows on Native Range When Fed Protein Supplements Containing Various Levels of Corn" (1990). Panhandle Research and Extension Center. 22.

https://digitalcommons.unl.edu/panhandleresext/22

This Article is brought to you for free and open access by the Agricultural Research Division of IANR at DigitalCommons@University of Nebraska - Lincoln. It has been accepted for inclusion in Panhandle Research and Extension Center by an authorized administrator of DigitalCommons@University of Nebraska - Lincoln. 


\title{
INTAKE AND DIGESTION OF LOW-QUALITY MEADOW HAY BY STEERS AND PERFORMANCE OF COWS ON NATIVE RANGE WHEN FED PROTEIN SUPPLEMENTS CONTAINING VARIOUS LEVELS OF CORN1
}

\author{
D. W. Sanson, D. C. Clanton and I. G. Rush ${ }^{2}$ \\ University of Nebraska $^{3}$, North Platte 69101 \\ ABSTRACT
}

\begin{abstract}
Two trials were conducted to evaluate the effects of corn in protein supplements fed to cattle receiving low-quality forages. In Trial 1 , four ruminally cannulated steers (avg BW $550 \mathrm{~kg}$ ) and four intact steers (avg BW $270 \mathrm{~kg}$ ) were used in a replicated latin square to determine intake and digestibility of a low-quality meadow hay $(4.3 \% \mathrm{CP})$ when fed no supplement (NS), $1.12 \mathrm{~g} \mathrm{CP} / \mathrm{kg} \mathrm{BW}$ (PS), $1.12 \mathrm{~g} \mathrm{CP} / \mathrm{kg}$ BW with corn supplying $1.98 \mathrm{~g}$ starch/kg BW (PLC) or $1.12 \mathrm{~g} \mathrm{CP} / \mathrm{kg}$ BW with com supplying $3.96 \mathrm{~g} \mathrm{starch} / \mathrm{kg} \mathrm{BW}$ (PHC). Hay DMI decreased $(P=.001)$ and total diet DMI increased $(P=.001)$ quadratically as supplemental corn increased. Diet DM digestibility increased $(P=.004)$ and forage DM and hemicellulose digestibility decreased $(P \leq .018)$ quadratically as level of corn in the diet increased. In Trial 2, 135 cows received either ear corn $(1.16 \mathrm{~kg}$ TDN and $127 \mathrm{~g}$ $\left.\mathrm{CP} \cdot \mathrm{hd}^{-1} \cdot \mathrm{d}^{-1}\right)$, ear com plus protein $\left(1.16 \mathrm{~kg}\right.$ TDN and $\left.290 \mathrm{~g} \mathrm{CP} \cdot \mathrm{hd}-1 \cdot \mathrm{d}^{-1}\right)$ or protein $(.72$ $\mathrm{kg}$ TDN and $290 \mathrm{~g} \mathrm{CP} \cdot \mathrm{hd}^{-1} \cdot \mathrm{d}^{-1}$ ) while grazing native Sandhills winter range for $112 \mathrm{~d}$ and while receiving hay $(10 \% \mathrm{CP})$ during the following $60-\mathrm{d}$ calving period. Cows that received ear corn lost $(P<.001)$ more weight than cows fed ear corn plus protein supplement, which lost more weight than cows fed only protein supplement $(-54,-18$ and $6 \mathrm{~kg}$, respectively) during the 112 -d winter grazing period. Cows that received ear corn and ear corn plus protein gained more $(P<.001)$ weight during calving and summer grazing (after supplement was withdrawn) than protein-supplemented cows. Reproductive performance was not affected $(P>.705)$ by treatments.
\end{abstract}

(Key Words: Beef Cattle, Corn, Digestibility, Intake, Performance, Protein)

J. Anim. Sci. 1990. 68:595-603

\section{Introduction}

The effect of supplementation on utilization of forage often is overlooked. Intake or digestion of low-quality forage may be depressed when cattle are fed supplements containing high amounts of cereal grains (Campbell et al., 1969; Chase and Hibberd, 1987). In contrast, intake of forage often increases when supplements containing protein from oil meal products are fed to cattle and

\footnotetext{
${ }^{1}$ Journal paper no. 8879, Univ. of Nebraska Agric. Res.

${ }^{2}$ Panhandle Res. and Ext. Center, Scottsbluff, NE

${ }^{3}$ West Central Res. and Ext. Center.

Received April 11. 1989.

Accepted June 29, 1989.
}

sheep (McCollum and Galyean, 1985; Krysl et al., 1987, Stokes et al., 1988).

Effects of supplements containing combinations of oil meals and cereal grains on forage utilization have been variable (Williams et al., 1953; Fontenot et al., 1955; Elliott, 1967a; Rittenhouse et al., 1969). Furthermore, performance of animals supplemented with various levels of protein and energy has not been consistent (Norman, 1963; Bellows and Thomas, 1976; Davis et al., 1977; Hennessy et al., 1981). Research reported in this paper was designed to study the effect of increasing amounts of corn in a protein supplement on intake and digestion of a low-quality meadow hay by steers and to evaluate performance of cows receiving ear corn with and without a conventional protein supplement. 
TABLE 1. FORMULATION AND DAIL Y NUTRIENT INTAKE OF PROTEIN SUPPLEMENTS FED IN TRIAL 1

\begin{tabular}{|c|c|c|c|}
\hline \multirow[b]{2}{*}{ Item } & \multicolumn{3}{|c|}{ Starch from corn, g/kg BW } \\
\hline & $\begin{array}{l}0 \\
(\mathrm{PS})^{\mathrm{a}}\end{array}$ & $\begin{array}{l}2 \\
(\mathrm{PLC})^{\mathrm{a}}\end{array}$ & $\begin{array}{l}4 \\
(\mathrm{PHC})^{\mathrm{a}}\end{array}$ \\
\hline \multicolumn{4}{|l|}{ Ingredient, q $^{\mathrm{b}}$} \\
\hline Com & & 57 & 77 \\
\hline Soybean meal & 70 & 35 & 23 \\
\hline Corn gluten meal & 28 & 7 & \\
\hline Monosodium phosphate & 2 & 1 & \\
\hline \multicolumn{4}{|l|}{ Nutrient, g/kg BWc } \\
\hline DM & 2.3 & 4.6 & 7.0 \\
\hline TDN & 1.7 & 3.5 & 5.4 \\
\hline Total protein & 1.12 & 1.12 & 1.12 \\
\hline Com protein & & .19 & .39 \\
\hline Corn gluten meal protein & .39 & .20 & \\
\hline $\begin{array}{l}\text { Soybean meal protein } \\
\text { Starch }\end{array}$ & .73 & $\begin{array}{r}.73 \\
1.98\end{array}$ & $\begin{array}{r}.73 \\
3.96\end{array}$ \\
\hline
\end{tabular}

"PS = protein-no com supplement; PLC = protein-low corn supplement; $\mathrm{PHC}=$ protein - high com .

${ }^{b} \mathrm{DM}$ basis.

${ }^{\mathrm{c} C a l c u l a t e d}$ values from feed tables (NRC, 1984).

\section{Experimental Procedures}

Trial 1. Four crossbred steers (avg BW 550 $\mathrm{kg}$ ), each fitted with a permanent $10.2-\mathrm{cm}$ i.d. ruminal cannula, and four crossbred intact steers (avg BW $270 \mathrm{~kg}$ ) were used in a replicated $4 \times 4$ latin square to determine intake and digestibility of grass hay when being fed isonitrogenous supplements containing various amounts of com. The four treatments (Table 1) were no supplement (NS) and three supplements each providing $1.12 \mathrm{~g} \mathrm{CP} /$ $\mathrm{kg}$ BW daily but providing different amounts of starch from corn. Each of the three supplements supplied $.73 \mathrm{~g} \mathrm{CP}$ from soybean meal $/ \mathrm{kg} \mathrm{BW}$. Corn gluten meal was used to adjust supplements to a constant com protein level. Hence, the protein-no corn supplement (PS) supplied $.39 \mathrm{~g}$ of CP from com gluten meal $/ \mathrm{kg} \mathrm{BW}$. The protein-low corn supplement (PLC) supplied .20 and $.19 \mathrm{~g}$ of $\mathrm{CP}$ from corn gluten meal and corn $/ \mathrm{kg} \mathrm{BW}$, respectively. The protein-high com supplement (PHC) supplied $.39 \mathrm{~g}$ of CP from corn $/ \mathrm{kg}$ BW (PHC). The three supplements supplied 0,2 and $4 \mathrm{~g}$ of starch from com $/ \mathrm{kg} \mathrm{BW}$, respectively. Forage was low-quality hay (Table 2), consisting of both warm- and cool-season grasses, harvested from a subirrigated meadow in August 1987 and chopped with a tub grinder through a 5-cm screen. Predominant warm-season species were big bluestem (Andropogon gerardii
Vitman), prairie sandreed (Calamovilfa longifolia [Hook.] Scribn.) and switchgrass (Panicum virgatum L.). Primary cool-season species were Kentucky bluegrass (Poa pratensis L.), smooth bromegrass (Bromus inermis Leyss.), redtop (Agrostis alba L.), timothy (Phleum pratense L.) and various wheatgrasses (Agropyron spp.). Steers were housed in partially covered individual pens $(6 \times 9 \mathrm{~m})$ with concrete floors and had continuous access to hay, water and iodized salt. Hay was fed each morning at 0700 after orts from the previous feeding were removed and weighed. Amount of hay offered daily equaled the previous day's consumption plus $20 \%$. Supplements, fed immediately after all animals received hay, were consumed within $1 \mathrm{~h}$ of feeding.

Each of the four periods lasted $29 \mathrm{~d}$. Seven days were allowed for diet adjustment. Hay intake was measured the following $14 \mathrm{~d}$. Ruminal fluid samples were taken from cannulated steers on d 22 and 23. From d 25 through 29, total feces were collected from the cannulated steers. The intact steers remained on their respective supplements during d 22 and through 29; however, feed intake data were not included in the analyses.

Ruminal fluid samples were taken from cannulated steers $1 \mathrm{~h}$ prior to supplement feeding on d 22 and at $2-\mathrm{h}$ intervals thereafter through $d 23$. On $d 22$, the 23-h sample also served as the $-1 \mathrm{~h}$ sample for $\mathrm{d} 23$. Ruminal contents were mixed prior to sampling. Upon removal from the rumen, $\mathrm{pH}$ of the sample was determined. Fluid strained from particles using four layers of cheesecloth was acidified $(1 \mathrm{ml}$ $20 \% \mathrm{H}_{2} \mathrm{SO}_{4} / 50 \mathrm{ml}$ ruminal fluid) and frozen at $-10^{\circ} \mathrm{C}$.

TABLE 2. CHEMICAL COMPOSITION OF HAY AND DAILY SUPPLEMENTS FED IN TRIAL 1

\begin{tabular}{|c|c|c|c|c|}
\hline \multirow[b]{2}{*}{ Item, $\%$} & \multirow[b]{2}{*}{ Hay } & \multicolumn{3}{|c|}{ Starch from com, $\mathrm{g} / \mathrm{kg} \mathrm{BW}$} \\
\hline & & $\begin{array}{l}0 \\
(\mathrm{PS})^{\mathrm{a}} \\
\end{array}$ & $\begin{array}{l}2 \\
(\mathrm{PLC})^{\mathrm{a}}\end{array}$ & $\begin{array}{l}4 \\
(\mathrm{PHC})^{\mathrm{a}} \\
\end{array}$ \\
\hline $\begin{array}{l}\text { CP } \\
\text { IVDMD }^{b}\end{array}$ & $\begin{array}{r}4.3 \\
49.2\end{array}$ & 48.5 & 24.5 & 16.0 \\
\hline NDF & 72.9 & 9.7 & 11.1 & 11.2 \\
\hline $\mathrm{ADF}$ & 46.2 & 7.1 & 5.2 & 4.1 \\
\hline Lignin & 6.2 & 1.7 & 1.2 & 1.2 \\
\hline Ash & 11.2 & 8.0 & 4.2 & 3.0 \\
\hline AlA & 8.2 & .3 & .7 & .1 \\
\hline
\end{tabular}

${ }^{2} \mathrm{PS}=$ protein-no com supplement; PLC = protein-low com supplement; $\mathrm{PHC}=$ protein-high corn.

${ }^{b}$ In vitro DM digestibility. 
Cannulated steers were fitted with fecal bags at 1800 on d 24 . Bags were changed at 0600 on d 25 and at 8 -h intervals through d 29 . Upon removal, individual bags containing feces were weighed, with the weight of the bag subtracted to determine feces weight. After weighing, feces in each bag were mixed and a $10 \%$ aliquot was stored at $2^{\circ} \mathrm{C}$ until the end of the period. Equal amounts of feces (wet weight basis) from daily aliquots were mixed for each animal at the end of each period and a subsample was processed for analysis. Hay, orts and supplements were sampled daily from d 24 through 28 . Ort samples were combined across days within treatment at the end of each period and subsampled. Samples of feces were dried at $60^{\circ} \mathrm{C}$ for $60 \mathrm{~h}$. Samples of corn, hay and orts were dried at $60^{\circ} \mathrm{C}$ for $24 \mathrm{~h}$. A representative sample of each also was dried at $100^{\circ} \mathrm{C}$ for $60 \mathrm{~h}$ to determine DM. Samples dried at $60^{\circ} \mathrm{C}$ were allowed to equilibrate at room temperature for $24 \mathrm{~h}$, ground through a 2-mm screen in a Wiley mill and then through a $1-\mathrm{mm}$ screen in a Udy cyclone mill. Samples were stored in airtight containers until analysis. During the intake portion of each study, daily samples of hay, orts and supplements were taken and combined after $7 \mathrm{~d}$. Subsamples of each were dried at $100^{\circ} \mathrm{C}$ for $60 \mathrm{~h}$ to determine DM.

Trial 2. One hundred thirty-five crossbred 4 to 9-year old cows in good condition were randomized within age and used in a completely randomized design to determine the effect of supplemental energy and protein on performance of cows and calves while grazing Sandhills winter range or receiving grass hay. This study was conducted at the Gudmundsen Sandhills Laboratory near Whitman, Nebraska. Three supplement treatments were used with three replications of each treatment. Supplement treatments were ear corn to supply 1.16 kg TDN plus $127 \mathrm{~g} \mathrm{CP} \cdot \mathrm{hd}^{-1} \cdot \mathrm{d}^{-1}$, ear com plus a protein supplement to supply $1.16 \mathrm{~kg}$ TDN plus $290 \mathrm{~g} \mathrm{CP} \cdot \mathrm{hd}^{-1} \cdot \mathrm{d}^{-1}$ and protein supplement (without ear corn) to supply $.72 \mathrm{~kg}$ TDN plus $290 \mathrm{~g} \mathrm{CP} \cdot \mathrm{hd}^{-1} \cdot \mathrm{d}^{-1}$. The protein supplement fed with ear corn was a commercially prepared, cubed, 32\% natural-protein supplement containing soybean meal, cottonseed meal, dehydrated alfalfa meal, other plant protein products and appropriate minerals and vitamin $\mathbf{A}$. The protein supplement fed without ear corn was a cubed, $40 \%$ natural-protein, supplement containing soybean meal and appropriate min- erals and vitamin A prepared in the feedmill at the West Central Research and Extension Center. The study was conducted through three phases of the annual cycle: winter grazing, calving and summer grazing. Supplements were fed only during the first two phases.

Cows grazed native range during the winter phase (112 d) of the study. The site was predominately choppy sands and sands in excellent condition. Dominant grasses were sand bluestem (Andropogon hallii Hack.), little bluestem ( $A$. scoparius Michx.), blue grama (Bouteloua gracilis [H.B.K.] Lag. ex Griffiths), hairy grama ( $B$. hirsuta Lag.), prairie sandreed (Calamovilfa longifolia [Hook.] Scribn), sand lovegrass (Eragrostis trichodes [Nutt.] Wood) and switchgrass (Panicum virgatum L.). Leadplant (Amorpha canescens Pursh) was the predominant shrub, with lesser amounts of other grasses and forbs present. During two previous winters, similar range forage collected via esophageally fistulated steers contained $5.0 \% \mathrm{CP}$ and $51 \%$ in vitro OM digestibility (Knott, 1983). Treatment groups were assigned randomly to one of nine pastures (approximately 44 ha each). Vegetative composition and condition of pastures were similar. Pastures had not been grazed the previous summer. Groups had continual access to a salt-dicalcium phosphate mixture (50:50). Supplements were fed on the ground $6 \mathrm{~d} / \mathrm{wk}$.

During the calving phase $(60 \mathrm{~d})$, cows were confined in .6-ha lots. Supplement treatments were continued during calving, with supplements fed in bunks. Cows had ad libitum access to a good-quality meadow grass hay (10\% CP; $58 \%$ in vitro DM digestion [IVDMD]), water and the salt-dicalcium phosphate mixture used in the winter. Supplementation stopped at the beginning of the summer phase (May 7). During the summer, cows grazed together in a native grass pasture until weaning (Oct. 10).

Cow weights were recorded after $16 \mathrm{~h}$ without feed and water at the beginning of the trial (winter), at calving, at the beginning of the summer phase and at weaning. Calves were weighed within $12 \mathrm{~h}$ of birth, at the beginning of the summer phase and at weaning. Data from cows (and from their calves) that had not calved more than $20 \mathrm{~d}$ prior to the onset of the summer phase were excluded from the analysis of the weight for that time. Cows were examined for pregnancy by rectal palpation at weaning. 
Analytical Procedures. Procedures outlined by AOAC (1975) were used to determine DM and ash of feed, fecal and ort samples and $\mathrm{CP}$ (Kjeldahl $\mathrm{N} \times 6.25$ ) of feed samples. All samples were analyzed for NDF, ADF and ADL using procedures described by Goering and Van Soest (1970). Hemicellulose (HCL) was expressed as the difference between NDF and ADF. Cellulose (CEL) was estimated as the weight of ADF lost in the ADL procedure prior to ashing. Determination of AIA in hay samples followed procedures outlined by Van Keulen and Young (1977). Hay samples were analyzed for IVDMD according to Tilley and Terry (1963). Starch values were taken from feed composition tables (Leonard and Martin, 1963).

Stored ruminal fluid samples were allowed to thaw overnight at room temperature. Samples were shaken vigorously after thawing to mix contents. The 50-ml samples were removed and centrifuged at $2,000 \times g$ for 10 min. Ammonia $\mathbf{N}$ was determined on the supernatant fluid, using the phenol-hypochlorite procedure outlined by Broderick and Kang (1980).

Calculations and Data Analysis. Hay DM and $\mathrm{OM}$ digestion coefficients were determined by the method described by Sanson and Clanton (1989) assuming supplement digestibility was equal to calculated TDN values (75, 76 and 77\% TDN for PS, PLC and PHC, respectively). Metabolizable energy intake of the hay in Trial 1 was estimated as $82 \%$ of DE (NRC, 1984). A DE value was calculated from the equation of Rittenhouse et al. (1971) where $\mathrm{DE}=.038(\% \mathrm{DM}$ digestibility $)+.18$, using the DM digestibility values for the hay from each treatment. Total ME intake was estimated by adding the calculated ME intake value for the supplement [(TDN $\times 4.4) .82=\mathrm{ME})]$ plus hay ME intake.

In Trial 2, calving interval was calculated for the 95 cows remaining in the herd during the following calving season. Calving interval was calculated by subtracting calving date during the trial from the subsequent calving date. Other cows were culled because of not rebreeding (16 hd) or due to age (24 hd).

Statistical procedures were those of SAS (1985). Intake and ruminal parameters in Trial 1 were analyzed by GLM procedures appropriate for a replicated latin square split-plot in time design. Day was considered the replicate for ruminal values and animals (four fistulated and four intact steers) served as replicates for the intake data. Reported values were pooled across time where there was no significant $(P$ $>.05)$ time $\times$ treatment interaction. When time $x$ treatment interactions were significant, data were analyzed and are reported within time. Diet digestibility data were analyzed with a GLM model for a latin square treatment design. When treatment effects were significant $(P<.05)$, orthogonal contrasts were examined to determine the effect of the average of supplementation treatments vs no supplement and within the supplement treatments to determine the linear and quadratic effects of corn content of supplements. When both linear and quadratic effects were significant $(P<.10)$, only the quadratic contrast is presented. In Trial 2, body weights, body weight changes, ADG, birth dates, conception rate and calving interval were analyzed with a GLM model for a one-way analysis of variance. Conception rates were transformed to a logit (Cox, 1970) before analysis by GLM. Mean values were separated by least significant differences when a significant treatment effect was observed $(P<.05)$.

\section{Results}

Trial 1 . No treatment $x$ day interaction $(P \geq$ .151) was observed for intake data; thus, means were pooled across days (Table 3 ). A quadratic effect $(P \leq .001)$ of level of supplemental corn was observed for forage intake. A $5 \%$ decrease in forage consumed occurred with the first increment of corn in the supplement, whereas the decrease was $17 \%$ between the first and second increment. Hay intake expressed as kilogram/day was higher $(P<.001)$ for animals that received supplements than for those that received no supplement; however, steers fed PHC actually consumed less forage than steers fed NS. Addition of com to the protein supplement also caused a quadratic $(P \leq .016)$ effect on total diet DM intake. Animals receiving PS or PHC had the same mean total intake $\left(10.6 \mathrm{~kg} \cdot \mathrm{hd}^{-1} \cdot \mathrm{d}^{-1}\right)$, whereas a mean intake level of 11.1 $\mathrm{kg} \cdot \mathrm{hd} \mathrm{d}^{-1} \cdot \mathrm{d}^{-1}$ was observed when steers received PLC. This was an increase in dietary intake of 4.7\%. Total diet DM intake was higher $(P=$ .001) when steers received a supplement than when they received no supplement.

Hay digestibility was calculated assuming supplements had constant digestibility at NRC 
TABLE 3. DAIL Y INTAKE OF LOW-QUALITY MEADOW HAY BY STEERS FED DIFFERENT SUPPLEMENTS

\begin{tabular}{|c|c|c|c|c|c|c|c|}
\hline \multirow[b]{2}{*}{ Intake } & \multicolumn{3}{|c|}{ Starch from corn, $\mathrm{g} / \mathrm{kg} \mathrm{BW}$} & \multirow[b]{2}{*}{$\begin{array}{l}\text { Control } \\
\text { (NS) }^{\mathrm{a}}\end{array}$} & \multirow[b]{2}{*}{ SE } & \multirow[b]{2}{*}{$\begin{array}{l}\text { Corn } \\
P\end{array}$} & \multirow{2}{*}{$\begin{array}{l}\text { Control vs } \\
\text { supplement } \\
P\end{array}$} \\
\hline & $\begin{array}{l}0 \\
(\mathrm{PS})^{a}\end{array}$ & $\begin{array}{l}2 \\
(\mathrm{PLC})^{\mathrm{a}}\end{array}$ & $\begin{array}{l}4 \\
(\mathrm{PHC})^{\mathrm{a}} \\
\end{array}$ & & & & \\
\hline \multicolumn{8}{|l|}{ DM } \\
\hline Hay, $\mathrm{kg}$ & 9.5 & 9.0 & 7.4 & 8.2 & .1 & $<.001^{b}$ & $<.001$ \\
\hline Hay, g/kg BW.75 & 95.4 & 89.7 & 72.8 & 82.7 & 1.5 & $.003^{b}$ & .056 \\
\hline Hay, \% BW & 2.1 & 2.0 & 1.6 & 1.8 & .04 & $.012^{\mathrm{b}}$ & .154 \\
\hline Total, kg & 10.6 & 11.1 & 10.6 & 8.2 & .1 & $<.001^{\mathrm{b}}$ & $<.001$ \\
\hline Total, g/kg BW.75 & 105.7 & 110.4 & 103.4 & 82.7 & 1.6 & $.004^{b}$ & $<.001$ \\
\hline Total, $\%$ BW & 2.3 & 2.4 & 2.2 & 1.8 & .05 & $.016^{\mathrm{b}}$ & $<.001$ \\
\hline \multicolumn{8}{|l|}{ Digestible DM } \\
\hline Hay, $\mathbf{k g}$ & 5.2 & 4.9 & 3.8 & 4.1 & .04 & $<.001^{\mathrm{b}}$ & $<.001$ \\
\hline Total, kg & 5.4 & 5.3 & 4.4 & 4.1 & .05 & $<.001^{b}$ & $<.001$ \\
\hline \multicolumn{8}{|l|}{ Estimated ME } \\
\hline Hay, Mcal & 17.8 & 16.5 & 13.0 & 13.9 & .14 & $<.001^{b}$ & $<.001$ \\
\hline Total, Mcal & 20.2 & 22.1 & 21.4 & 13.9 & .16 & $<.001^{b}$ & $<.001$ \\
\hline
\end{tabular}

${ }_{\text {a }} \mathrm{PS}=$ protein-no corn supplement; PLC = protein-low corn supplement; $\mathrm{PHC}=$ protein-high corn; NS = no supplement.

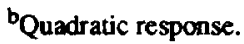

(1988) levels. Hay digestible DM intake responded quadratically $(P<.001)$ to level of corn in the supplement. An initial decrease of $6 \%$ was observed for the first level of corn and a further decrease of $21 \%$ was observed with further addition of corn. Although only a small difference in total digestible DM intake occurred between PS and PLC, PHC resulted in an $18 \%$ depression of total digestible DM intake. Hay and total DM intake was higher when animals received supplements compared with no supplement. Metabolizable energy intakes responded quadratically $(P<.001)$ to increased level of corn. Hay ME intake was decreased by $7.3 \%$ when corn was included in the supplement and depressed an additional 9.2\% when the level of corn increased. However, total diet ME intake was highest for PLC followed by PHC and lowest for PS. Mean total intake of ME was increased by $60 \%$ when supplement was fed compared to NS.

A quadratic effect $(P \leq .057)$ was observed for DM and OM digestion due to supplemental corn (Table 4). Mean apparent DM digestion increased $4.5 \%$ from the PC to PLC treatment

TABLE 4. DIGESTION COEFFICIENTS FOR FORAGE AND DIETS OF STEERS FED LOW-QUALITY MEADOW HAY AND SUPPLEMENTED WITH DIFFERENT LEVELS OF PROTEIN AND ENERGY

\begin{tabular}{|c|c|c|c|c|c|c|c|}
\hline \multirow[b]{2}{*}{ Digestibility, \% } & \multicolumn{3}{|c|}{ Starch from com, $\mathrm{g} / \mathrm{kg} \mathrm{BW}$} & \multirow[b]{2}{*}{$\begin{array}{l}\text { Control } \\
(\mathrm{NS})^{\mathrm{a}}\end{array}$} & \multirow[b]{2}{*}{ SE } & \multirow[b]{2}{*}{$\begin{array}{l}\text { Corn } \\
P\end{array}$} & \multirow{2}{*}{$\begin{array}{l}\text { Control vs } \\
\text { protein } \\
P\end{array}$} \\
\hline & $\begin{array}{l}0 \\
(\mathrm{PS})^{\mathrm{a}}\end{array}$ & $\begin{array}{l}2 \\
(P L C)^{\circledR}\end{array}$ & $\begin{array}{l}4 \\
(\mathrm{PHC})^{\mathrm{a}}\end{array}$ & & & & \\
\hline Apparent DM & 56.68 & 59.21 & 60.00 & 49.48 & 1.00 & $.057^{b}$ & $<.001$ \\
\hline Apparent OM & 60.20 & 62.82 & 64.27 & 54.36 & .82 & $.013^{b}$ & $<.001$ \\
\hline NDF & 52.68 & 51.07 & 49.49 & 49.96 & .70 & $.018^{b}$ & .212 \\
\hline ADF & 48.60 & 46.73 & 46.51 & 44.08 & .91 & $.157^{\mathrm{b}}$ & .023 \\
\hline Hemicellulose & 59.76 & 58.42 & 54.32 & 60.49 & 1.30 & $.025^{b}$ & .093 \\
\hline Cellulose & 68.62 & 71.32 & 67.78 & 67.79 & 2.65 & TNS $^{\mathrm{d}}$ & TNS $^{\mathrm{d}}$ \\
\hline Hay $D^{e}$ & 54.48 & 54.54 & 51.97 & 49.48 & 1.34 & $.237^{\mathrm{b}}$ & .036 \\
\hline Hay $\mathrm{OM}^{\mathrm{e}}$ & 58.28 & 58.71 & 57.67 & 54.36 & .93 & $.542^{\mathrm{c}}$ & .012 \\
\hline
\end{tabular}

${ }^{\text {a} P S ~=~ p r o t e i n-n o ~ c o r n ~ s u p p l e m e n t ; ~ P L C ~=~ p r o t e i n-l o w ~ c o m ~ s u p p l e m e n t ; ~} \mathrm{PHC}=$ protein-high com; NS = no supplement.

binear.

cQuadratic.

Treatment effect not significant $(P>10)$.

${ }^{\circ}$ Calculated assuming supplement digestibility = TDN value. 


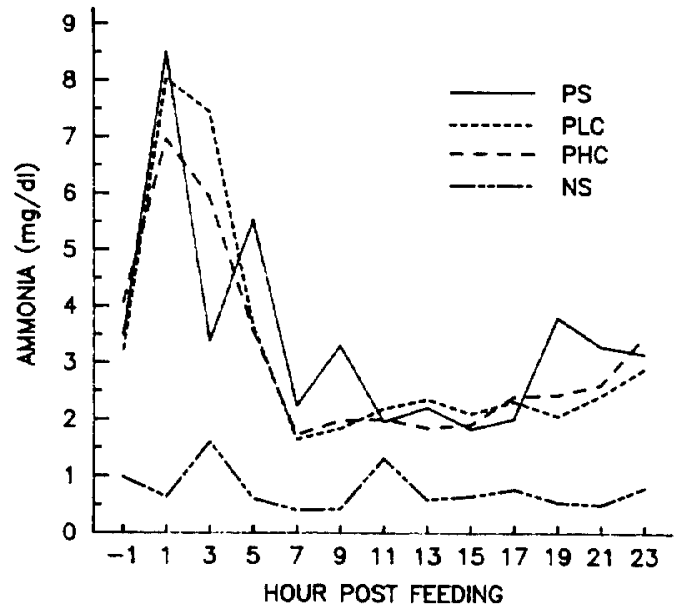

Figure 1. Ruminal ammonia of steers receiving different levels of supplemental com.

and $1.3 \%$ from PLC to PHC treatment. Supplementation improved $(P \leq .001)$ both DM and OM digestion compared with no supplement. Neutral detergent fiber digestion was decreased quadratically $(P=.018)$ as level of com in the supplement increased; however, averaged across supplements, supplementation did not improve $(P=.212) \mathrm{NDF}$ digestion compared with no supplement. Acid detergent fiber digestion was not different $(P=.157)$ among corn supplements, but digestion of ADF was improved $(P=.023)$ by supplementation compared with no supplement. A quadratic effect $(P=.025)$ for HCL digestion was observed due to adding corn to the supplement. Digestion of HCL decreased $2 \%$ from PS to PLC treatment and an additional $7 \%$ from PLC to PHC treatment. Cellulose digestion was not affected by treatment $(P>.758)$. Level of corn in the supplement did not affect $(P \geq .237)$ hay DM or OM digestion, although supplementation did increase $(P \leq .036)$ digestion of hay $\mathrm{DM}$ and $\mathrm{OM}$.

Because of a treatment $\times$ hour interaction $(P$ $\geq .100$ ), ruminal data are presented by hour. Adding corn to the supplement caused a quadratic effect $(P<.012)$ on ruminal fluid ammonia at $\mathrm{h}-1,1,7,17,21$ and 23 and a linear effect at h $3,5,13$ and 15 (Figure 1). There was no effect $(P \geq .114)$ at $h 9,11$ and 19. In general, level of corn supplementation did not greatly affect ruminal ammonia.

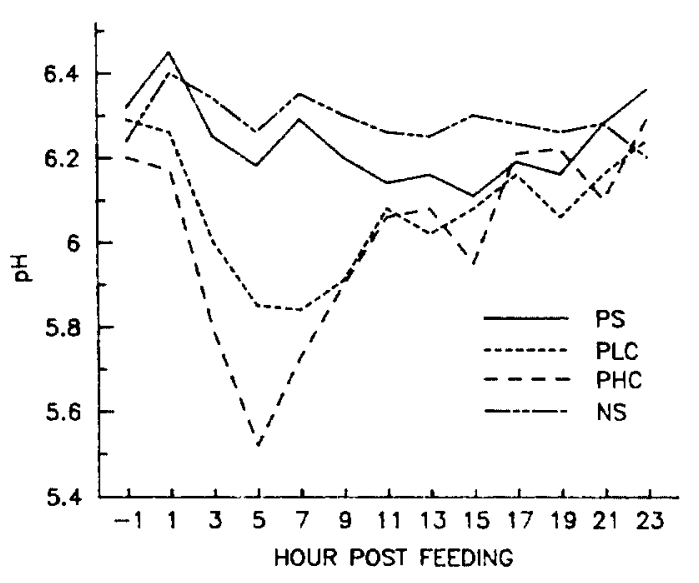

Figure 2. Ruminal $\mathrm{pH}$ of steers receiving different levels of supplemental com.

Supplementation increased ammonia levels at all hours compared with no supplement.

Ruminal fluid pH (Figure 2) responded in a quadratic manner $(P \leq .051)$ at h $1,3,5,7,9$, 13 and 15 and linearly $(P=.031)$ at $h 19$ due to level of corn in the supplement. The major depression in $\mathrm{pH}$ was observed at $\mathrm{h} 1,3,5$ and 7 for PLC and PHC treatments; the ruminal fluid $\mathrm{pH}$ dropped below 6 at $\mathrm{h} 3,5,7$ and 9 for these treatments. Supplementation decreased $(P \leq .034)$ ruminal fluid $\mathrm{pH}$ at $\mathrm{h} 1,3,5$ and 7 compared with no supplementation.

Trial 2. Cows that received ear com lost more weight during winter grazing than cows that received ear corn plus protein supplement (Table 5); both groups lost more weight than cows that received only protein supplement ( $P$ $<.001)$. However, both groups that received ear com gained more weight $(P<.001)$ than the protein-supplemented cows (no ear corn) during the calving phase when grass hay was fed. Both groups of cows fed ear corn gained weight and the group that received only protein supplement lost weight during the calving phase. Cows that received only protein supplement gained $16 \mathrm{~kg}$ during the summer phase, whereas those that received ear corn gained $46 \mathrm{~kg}(P<.001)$. During the summer phase, even though no supplements were fed, those that had received only ear corn earlier gained faster than those that received ear corn and protein supplement earlier. Body weight changes during the entire trial were similar for 
PROTEIN SUPPLEMENTS CONTAINING CORN

TABLE 5. WEIGHT CHANGES OF COWS SUPPLEMENTED WITH EAR CORN AND(OR) PROTEIN SUPPLEMENT (TRIAL 2)

\begin{tabular}{|c|c|c|c|c|c|}
\hline Item & Ear com & $\begin{array}{l}\text { Ear com } \\
+ \text { protein }\end{array}$ & Protein & SE & $P$ \\
\hline Initial wt, kg & 528 & 523 & 525 & 7 & TNS $^{\mathrm{a}}$ \\
\hline \multicolumn{6}{|l|}{ Wt gain, kg } \\
\hline Winter & $-54^{b}$ & $-18^{c}$ & $6^{d}$ & 3 & .001 \\
\hline Calving & $5^{b}$ & $1^{b}$ & $-20^{c}$ & 3 & .001 \\
\hline Summer & $46^{b}$ & $23^{c}$ & $16^{d}$ & 4 & .001 \\
\hline Trial & $-8^{b}$ & $4^{c}$ & $3^{c}$ & 3 & .010 \\
\hline
\end{tabular}

Treatment effect not significant $(P>.05)$.

$b, c, d$ Row means with different superscripts are different.

both groups that received protein supplement ( 4 and $3 \mathrm{~kg}$ ), whereas cows that received only ear corn lost $8 \mathrm{~kg}(P=.01)$

Cows that received only protein supplement calved later $(P=.034)$ than those that received ear com (Table 6), although mean differences were only 3 or $4 \mathrm{~d}$. There was no effect $(P=$ .713) of treatment on birth weight. Supplementation with only ear corn decreased $(P \leq .042)$ calf weight and calf ADG from birth to the end of the calving phase compared to those that received protein supplement; however, weaning weights were similar among all treatments $(P=.115)$. Calves whose dams received protein supplement only were younger $(P=$ .042) at weaning due to the later mean calving date for this treatment.

Conception rate was not affected $(P=.705)$ among treatments $(87,91$ and $91 \%$ for ear corn, ear corn plus protein and protein, respectively). Conception date following supplementation and subsequent calving date of the cows remaining in the herd also were not affected $(P \geq .700)$ by treatment.

\section{Discuselon}

The decrease in forage intake by steers in Trial 1 as level of corn was increased in the supplement agrees with reports by Elliott (1967a) working with cattle and with Fontenot et al. (1955) and Elliott (1967b) with sheep. In our study, the feeding level of PLC supplied $.26 \%$ of BW of com; feeding PHC supplied $.52 \%$ of BW of com. Increasing level of com from 0 to $.26 \%$ of $B W$ resulted in a decrease in hay intake by $5 \%$. Increasing the level of corn intake from .26 to $.52 \%$ of $\mathrm{BW}$ resulted in a $17 \%$ depression in hay intake. In a previous study, Sanson and Clanton (1989) fed whole corn at $.25 \%$ or $.50 \%$ of $\mathrm{BW}$ to steers that received a low-protein hay. The $.25 \%$ lowered intake $3 \%$ and the $.50 \%$ lowered intake $20 \%$. This would indicate that there is not an interaction between protein and energy in the supplement, but that even when the protein requirement of the animal is met, supplementing low-quality forage with com will decrease forage intake.

These data suggest that when protein is adequate in the diet, high levels of corn feeding (52\% of BW) will depress fiber digestion. Similar results have been reported by Chase and Hibberd (1987). The quadratic effect observed indicates that forage digestibility is not affected at low levels of com feeding. This same observation was made by Sanson and Clanton (1989).

Ruminal fluid $\mathrm{pH}$ and ammonia levels at $\mathrm{h}$ $1,3,5$ and 7 post-supplementation suggest that fermentation of readily available carbohydrates increased as level of com in the diet increased. Ruminal fluid ammonia levels of PS, PLC and PHC steers were above the recommended levels for maximum microbial growth (2 to 5 $\mathrm{mg} / \mathrm{dl}$ ) suggested by Satter and Slyter (1974), so fiber digestion should not have been depressed by low ammonia levels. However, ruminal fluid $\mathrm{pH}$ of steers receiving PLC and PHC was less than 6.0 at $h 3,5,7,9,11,13$ and 15. A similar trend was observed by Mould and Orskov (1983) with grain supplementation. Depression in cellulolytic enzyme activity (Smith et al., 1973) and numbers of cellulolytic bacteria (Russell and Dombrowski, 1980) have been reported when $\mathrm{pH}$ was below 6.0. However, Chase et al. (1988) did not observe a difference in cellulose digestion when $\mathrm{pH}$ was maintained above 6.4 compared to $\mathrm{a} \mathrm{pH}$ between 5.8 to 6.2 . Cellulose digestibility was not altered in the present study, although digestibilities of NDF and $\mathrm{HCl}$ 
TABLE 6. PERFORMANCE OF CALVES WHOSE DAMS RECEIVED EAR CORN AND(OR) PROTEIN SUPPLEMENTATION (TRIAL 2)

\begin{tabular}{|c|c|c|c|c|c|}
\hline Item & Ear corn & $\begin{array}{l}\text { Ear com } \\
+ \text { protein }\end{array}$ & Protein & SE & $P$ \\
\hline Birth date & Mar. $29^{a}$ & $\operatorname{Mar} .31^{\mathrm{ab}}$ & Apr. $3^{b}$ & 1.4 & .034 \\
\hline Birth w. kg & 44 & 44 & 44 & 1 & TNS $^{\mathrm{C}}$ \\
\hline Spring wt, kg & $72^{2}$ & $78^{b}$ & $78^{b}$ & 2 & .028 \\
\hline Spring ADG, kg & $.74^{\mathrm{a}}$ & $.88^{b}$ & $.87^{b}$ & .03 & .042 \\
\hline Wean wt, kg & 224 & 230 & 225 & 4 & TNS $^{\mathrm{C}}$ \\
\hline Wean age, day & $194^{2}$ & $193^{a b}$ & $189^{b}$ & 1.5 & .042 \\
\hline Wean ADG, kg & .93 & .96 & .96 & .01 & TNS $^{\mathrm{C}}$ \\
\hline
\end{tabular}

, b $\mathrm{B}$ Row means without a common letter in their superscripts differ.

Treatment effect not significant $(P>.05)$.

were depressed. The suppression of ruminal fluid $\mathrm{pH}$ at higher levels of com feeding did not affect hay DM digestion.

In Trial 2, cows fed ear com lost $10 \%$ of their BW during the winter phase, indicating the animals were in a severe negative nutrient balance. The assumption that lack of energy contributed to poorer performance was not supported by the fact that cows fed ear corn plus a protein supplement did not perform as well as those fed only protein supplement. Evidently, factors other than protein deficiency were involved. Data from Trial 1 suggest that forage intake and fiber digestibility were decreased in cows fed ear corn.

Weight changes of the cows during the calving season would indicate that com did not have an adverse effect on the utilization of the medium-quality hay fed during that time. Cows that received ear com gained $5 \mathrm{~kg}$ and cows that received ear corn plus protein supplement gained $1 \mathrm{~kg}$ during the calving season, although they experienced the loss of weight due to calving. Others have reported improved performance with cattle and sheep fed medium-quality (Allden, 1959; Allden and Tudor, 1976) or high-quality forages (Lake et al., 1974; Coleman et al., 1976; Denham, 1977) and supplemented with grain. Calves from the cows supplemented with ear corn gained less weight from birth to time of going to summer pasture than did calves from cows fed the supplements with protein; this implies that the higher gain of $\mathrm{BW}$ in cows receiving only ear corn was at the expense of milk production. There were no differences in weaning weight of the three groups of calves. Ansotegui (1986) found that calves will increase forage intake to compensate for reduced milk intake and will have DE intakes similar to those of calves receiving more milk. If milk production was lower in cows receiving ear com in this study, their calves may have compensated by increasing forage intake.

The reproductive performance of the cows in the different treatment groups was not different $(P>.05)$. Wiltbank et al. (1962) reported that cows that lost $10 \%$ of their $\mathrm{BW}$ prior to calving had conception rates similar to those of contemporaries that gained $6 \%$ of their $\mathrm{BW}$ prior to calving providing that the plane of nutrition was increased post-calving.

\section{Implications}

When the level of supplemental corn was increased from $.26 \%$ of $\mathrm{BW}$ to $.52 \%$ of $\mathrm{BW}$, a $17 \%$ decrease in intake and $21 \%$ decrease in digestibility of low-quality forage was observed. Cows grazing native range lost more weight when supplemented with a protein supplement plus ear com than with a protein supplement alone. Addition of com to supplements for cattle fed low-quality forages should be done in moderation in order to prevent a suppression of intake and digestibility of the forage, which subsequently decreases animal performance.

\section{Literature Cited}

Allden. W. G. 1959. The summer nutrition of weaner sheep: The relative roles of available energy and protein when fed as supplements to sheep grazing mature pasture herbage. Aust. J. Agric. Res. 10:219.

Allden, W. G. and G. D. Tudor. 1976. Energy and nitrogen supplementation of grazing beef cattle in a Mediterranean environment. Proc. Aust. Soc. Anim. Prod. 11: 345.

Ansotegui, R. P. 1986. Chemical composition and rumen digesta kinetic of diets selected and influence of milk intake on forage intake by suckling calves grazing native range. Ph.D. Dissertation. New Mexico State Univ., Las Cruces. 
AOAC. 1975. Official Methods of Analysis (12th Ed.). Association of Official Analytical Chemists, Washing ton, DC.

Bellows, R. A. and O. O. Thomas. 1976. Some effects of supplemental grain feeding on performance of cows and calves on range forage. J. Range Manage. 29:192.

Broderick, G. A. and J. P. Kang. 1980. Automaled simultaneous determination of ammonia and cotal amino acids in numen fluids and in vitro media. J. Dairy Sci. 33:64.

Campbell, C. B., L. B. Sherrod and S. M. Ishizaki. 1969. Effect of supplemental protein and energy levels on the utilization of Kiluyu grass (pennisetum clandestinum). J. Anim. Sci. 29:634.

Chase, C. C., Jr. and C. A. Hibberd. 1987. Utilization of lowquality native grass hay by beef cows fed increasing quantities of corn grain. J. Anim. Sci. 65:557.

Chase, C. C., Jr., C. A. Hibberd and F. N. Owens. 1988. Buffer and ammonia additions to com-supplemented native grass hay diets for beef heifers. J. Anim. Sci. 66: 1790

Coleman, S. W., F. M. Pate and D. W. Beardsley. 1976. Effect of level of supplemental energy fed grazing steers on performance during the pasture and subsequent drylot period. J. Anim. Sci. 42:27.

Cox, D. R. 1970. Analysis of Binary Data. Chapman and Hall, London.

Davis, D., R. R. Schalles, G. H. Kiracofe and D. L. Good. 1977. Influence of winter nutrition on beef cow reproduction. J. Anim. Sci. 45:430.

Denham, A. H. 1977. Influence of energy and protein supplements on grazing and feedlot performance of steers. J. Anim. Sci. 45:1.

Elliott, R. C. 1967 a. Voluntary intake of low-protein diets by ruminants. I. Intake of food by cattle. J. Agric. Sci. (Camb.) 69:375.

Elliott, R. C. $1967 \mathrm{~b}$. Voluntary intake of low-protein diets by numinants. II. Intake of food by sheep. I. Agric. Sci. (Camb.) 69:383.

Fontenot, J. P., W. D. Gallup and A. B. Nelson. 1955. Effect of added carbohydrate on the utilization by steers of nitrogen in wintering rations. J. Anim. Sci. 14:807.

Goering, H. K. and P. J. Van Soest. 1970. Forage fiber analysis (apparatus, reagents, procedures, and some applications). Agric. Handbook 379. ARS, USDA, Washington, DC

Hennessy, D. W., P. J. Williamson, R. F. Lowe and D. R. Baigient. 1981. The role of protein supplements in nutrition of young grazing cattle and their subsequent productivity. J. Agric. Sci. (Camb.) 96:205.

Knot, M. J. 1983. Diet quality of steers grazing native Sandhills range and cornstalks. M. S. Thesis. Univ. of Nebraska, Lincoln.

Krysl, L. J., M. E. Branine, M. L. Galyean, R. E. Estell and W. C. Hoefler. 1987. Influence of cottonseed meal supplementation on voluntary intake ruminal and cecal fermentation, digesta kinetics and serum insulin and growth hormone in mature ewes fed prairie hay. J. Anim. Sci. 64:1178.

Lake, R. P., R. L. Hilebrand, D. C. Clanton and L. E. Jones. 1974. Limited energy supplementation of yearling steers grazing irrigated pasture and subsequent feedlot performance. J. Anim. Sci. 39:827.

Leonard, W. H. and J. H. Martin. 1963 Composition, processed products, and utilization. In: Cereal Crops. pp 202-218. Macmillan Co., London.

McCollum, F. T. and M. L. Galyean. 1985. Influence of cottonseed meal supplementation on voluntary intake, rumen fermentation and rate of passage of prairie hay in beef steers. J. Anim. Sci. 60:570.

Mould, F. L. and E. R. Orskov. 1983. Manipulation of rumen fluid $\mathrm{pH}$ and its influence on cellulolysis in sacco dry matter degradation and the rumen microflora of sheep offered either hay or concentrate. Anim. Feed. Sci. Technol. 10:31.

Norman, M. J. T. 1963. Dry season protein and energy supplements for beef cattle on native pastures at Katherine, N. T. Aust. J. Exp. Agric. Anim. Husb. 3: 1963.

NRC. 1984. Nutrient Requirements of Beef Cattle (6th Rev. Ed.). National Academy Press, Washington, DC.

Rittenhouse, L. R. D. C. Clanton and C. L. Streeter. 1970 Intake and digestibility of winter-range forage by cattle with and without supplements. J. Anim. Sci. 31:1215.

Rittenhouse, L. R. C. L. Streeter and D. C. Clanton. 1971 Estimating digestible energy from digestible dry and organic matter in diets of grazing cattle. J. Range Manage. 24:73.

Russell, J. B. and D. B. Dombrowski. 1980. Effect of pH on the efficiency of growth by pure cultures of rumen bacteria in continuous culture. Appl. Environ. Microbiol. 39:604

Sanson, D. W. and D. C. Clanton. 1989. Intake and digestibility of low-quality meadow hay by cattle receiving various levels of whole shelled com. J. Anim. Sci. 67 : 2854

SAS. 1985. SAS User's Guide; Statistics. SAS Inst., Inc., Cary, NC.

Satter, L. D. and L. L. Slyter. 1974. Effects of ammonia concentration on rumen microbial protein production in vitro. Br. J. Nutr. 32:199.

Smith, W. R., T. Yu and R. E. Hungate. 1973. Factors affecting cellulolysis by Ruminococcus albus. J. Bacteriol. 114:729.

Stokes, S. R., A. L. Goetsch, A. L. Jones and K. M. Landis 1988. Feed intake and digestion by beef cows fed prairie hay with different levels of soybean meal and receiving postruminal administration of antibiotics. J. Anim. Sci. 66:1778.

Tilley, J. M. and R. A. Terry. 1963. A two-stage technique for the in vitro digestion of forage crops. J. Br. Grassl. Soc. 18:104.

Van Keulen, J. and B. A. Young. 1977. Evaluation of acidinsoluble ash as a natural marker in ruminan digestibility studies. J. Anim. Sci. 44:282.

Williams, Y. J., N. C. Nottle, R. J. Moore and E. J. Underwood. 1953. Ruminal flora studies in sheep. IV. The influence of varying levels of protein and starch upon digestibility, nitrogen retention and free microorganisms of the rumen. Aust. J. Biol. Sci. 6:142

Wiltbank, J. N., W. W. Rowden, J. E. Ingulls, K. E. Gregory and $R$. M. Koch. 1962. Effect of energy level on reproductive phenomena of mature Hereford cows. J. Anim. Sci. 21:219. 